\title{
PENERAPAN PEER TEACHING PADA PELAJARAN IPS MATERI EKONOMI UNTUK MENINGKATKAN KEMAMPUAN BERPIKIR KRITIS SISWA KELAS VII 1 SMP NEGERI 1 PASAR BARU KABUPATEN SIMALUNGUN TAHUN 2017/2018
}

\author{
Oleh: \\ Baginda Halim Simatupang
}

\begin{abstract}
Abstrak
Model Peer Teaching merupakan pendekatan pembelajaran di mana siswa mengajarkan sesama teman, yaitu suatu metode mengajar yang dibantu oleh temannya sendiri. Penelitian ini bertujuan untuk mengetahui apakah dengan penerapan model Peer Teaching pada pembelajaran IPS dapat meningkatkan kemampuan berpikir kritis dan hasil belajar IPS siswa kelas VII 1 SMP Negeri 1 Pasar Baru Kabupaten Simalungun Tahun 2017/2018. Teknik analisis data yang digunakan yaitu teknik analisis deskriptif kualitatif. Hasil penelitian menunjukkan berdasarkan hasil tes, kemampuan berpikir kritis yang diperoleh siswa pada siklus I dengan nilai rata-rata sebesar 73,40 dan ketuntasan klasikal 64\%, siklus II dengan nilai rata-rata sebesar 77,20 dan ketuntasan klasikal 80\%, dan siklus III dengan nilai rata-rata sebesar 80,60 dan ketuntasan klasikal 88\%. Sedangkan hasil belajar yang diperoleh siswa pada siklus I dengan nilai rata-rata sebesar 73,20 dan ketuntasan klasikal sebesar 68\%, siklus II dengan nilai rata-rata sebesar 76,60 dan ketuntasan klasikal sebesar 76\%, siklus III dengan nilai rata-rata sebesar 80,20 dengan pencapaian ketuntasan sebesar $84 \%$. Penerapan model Peer Teaching dapat meningkatkan kemampuan berpikir kritis dan hasil belajar siswa.
\end{abstract}

Kata kunci: model peer teaching, kemampuan berpikir kritis, hasil belajar siswa. 


\section{PENDAhuluan}

Pembelajaran berasal dari kata belajar yang berarti adanya perubahan pada diri seseorang. Perubahan yang dimaksud mencakup aspek kognitif, afektif, maupun psikomotor. Dengan demikian, pembelajaran dapat diartikan proses yang dirancang untuk mengubah diri seseorang, baik aspek kognitif, afektif maupun psikomotornya (Suwardi, 2007: 30).

Upaya melakukan perbaikan di bidang pendidikan menjadi tanggung jawab semua pihak, salah satunya yaitu guru. Sebagaimana dijelaskan oleh Hamzah B. Uno (2008:17) bahwa "Seorang guru sangat berpengaruh terhadap hasil belajar yang dapat ditunjukkan oleh peserta didiknya". Oleh karena itu perubahan-perubahan berkaitan dengan tugas mengajar guru harus selalu ditingkatkan. Salah satu cara yang dapat ditempuh berkaitan dengan inovasi tugas mengajar guru adalah guru hendaknya mempunyai kemampuan dalam mengembangkan metode mengajarnya. Salah satu metode pembelajaran yang dapat digunakan oleh guru dalam pembelajaran adalah metode Peer Teaching.

Menurut UU nomor 20 tahun 2003 tentang Sistem Pendidikan Nasional Bab II pasal 3, pendidikan nasional berfungsi mengembangkan kemampuan dan membentuk watak serta peradaban bangsa yang bermartabat dalam rangka mencerdaskan kehidupan bangsa, bertujuan untuk berkembangnya potensi agar menjadi manusia yang beriman dan bertaqwa kepada Tuhan Yang Maha Esa, berakhlak mulia, sehat, berilmu, cakap, kreatif, mandiri, dan menjadi warga negara yang demokratis serta bertanggung jawab. Pendidikan nasional diarahkan untuk mengembangkan potensi yang dimiliki siswa sehingga menjadi manusia yang beriman dan bertaqwa kepada Tuhan Yang Maha Esa, berakhlak mulia, sehat, berilmu, cakap, kreatif, mandiri, demokratis serta bertanggung jawab, oleh karena itu setiap tahap dari proses belajar mengajar yang dirancang dan diselenggarakan harus diarahkan secara nyata pada pencapaian tujuan sistem pendidikan nasional. Upaya melakukan perbaikan di bidang pendidikan menjadi tanggung jawab semua pihak, salah satunya yaitu guru. Dari penjelasan di atas disebutkan bahwa pendidikan nasional diarahkan untuk mengembangkan potensi yang 
dimiliki siswa sehingga menjadi manusia yang beriman dan bertaqwa kepada Tuhan Yang Maha Esa, berakhlak mulia, sehat, berilmu, cakap, kreatif, mandiri, demokratis serta bertanggung jawab, oleh karena itu setiap tahap dari proses belajar mengajar yang dirancang dan diselenggarakan harus diarahkan secara nyata pada pencapaian tujuan sistem pendidikan nasional.

Penggunaan metode pembelajaran yang tepat dan disesuaikan dengan tujuan pembelajaran diharapkan akan menghasilkan prestasi belajar yang lebih baik. Suatu metode pembelajaran, khususnya pada mata pelajaran IPS belum tentu sesuai untuk setiap kompetensi dasar. Guru sebaiknya inovatif dalam memilih metode pembelajaran yang tepat dengan materi pembelajaran yang disajikan, agar terjadi proses pembelajaran yang komunikatif antara guru dan siswa. Untuk mencapai tujuan pembelajaran tersebut diperlukan suatu model pembelajaran yang sesuai dengan tujuan pendidikan, fasilitas, karakteristik siswa, guru, dan materi pelajaran.

Metode pembelajaran yang digunakan oleh guru sangat mempengaruhi tercapainya sasaran belajar sehingga guru perlu memilih metode yang tepat dari sekian banyak metode. Pemilihan metode pembelajaran tidak hanya didasarkan pada kebiasaan, melainkan pada bagaimana cara membuat siswa menjadi aktif dan memiliki minat belajar tinggi.

Menurut Amir (2010: 21) Peer Teaching merupakan metode instruksional yang menantang mahasiswa/siswa agar "belajar untuk belajar", bekerja sama dalam kelompok untuk mencari solusi bagi masalah yang nyata. Masalah ini digunakan untuk mengaitkan rasa keingintahuan serta kemampuan analisis siswa dan inisiatif atas materi pelajaran Peer Teaching. Sanjaya (2008: 46) Peer Teaching dapat diartikan sebagai rangkaian aktivitas pembelajaran yang menekankan kepada proses penyelesaian masalah yang dihadapi secara ilmiah.

Menurut Nurhadi (2004: 109), Peer Teaching adalah suatu model pembelajaran yang menggunakan masalah dunia nyata sebagai suatu konteks bagi siswa untuk belajar tentang cara berpikir kritis dan keterampilan pemecahan masalah serta untuk memperoleh pengetahuan dan konsep yang esensial dari materi pelajaran. 
Sedangkan menurut Arends (2007: 43), bahwa esensi Peer Teaching menyuguhkan berbagai situasi bermasalah yang autentik dan bermakna kepada peserta didik, yang dapat berfungsi sebagai batu loncatan untuk investigasi dan penyelidikan. Peer Teaching dirancang untuk membantu peserta didik mengembangkan keterampilan berpikir dan keterampilan menyelesaikan masalah, mempelajari peranperan orang dewasa dan menjadi pelajar yang mandiri. Model ini menyediakan sebuah alternatif yang menarik bagi guru yang menginginkan maju melebihi pendekatanpendekatan yang lebih berpusat pada guru untuk menantang peserta didik dengan aspek pembelajaran aktif dari model itu.

Berdasarkan pengertian di atas dapat disimpulkan bahwa Peer Teaching adalah suatu pendekatan pembelajaran di mana siswa dihadapkan pada suatu masalah yang kemudian dengan melalui pemecahan masalah itu siswa belajar kemampuankemampuan melalui penyelidikan dan berpikir sehingga dapat memandirikan peserta didik dalam belajar dan memecahkan masalah.

Menurut Nurhadi (2004: 111) pembelajaran berbasis masalah terdiri dari lima tahapan utama yang dimulai dengan guru memperkenalkan siswa dengan situasi masalah dan diakhiri dengan penyajian dan analisis hasil kerja siswa. Senada dengan hal tersebut tahapan model Peer Teaching tertuang dalam pola urutan alur tahap-tahap keseluruhan yang disertai dengan serangkaian kegiatan pembelajaran seperti tabel berikut (Trianto, 2009: 98).

Menurut Halpen dalam Achmad (2007), berpikir kritis adalah memberdayakan ketrampilan atau strategi kognitif dalam menentukan tujuan. Proses tersebut dilalui setelah menentukan tujuan, mempertimbangkan, dan mengacu langsung kepada sasaran-merupakan bentuk berpikir yang perlu dikembangkan dalam rangka memecahkan masalah, merumuskan kesimpulan, mengumpulkan berbagai kemungkinan, dan membuat keputusan ketika menggunakan semua keterampilan tersebut secara efektif dalam konteks dan tipe yang tepat.

Menurut Johnson (2014: 187) berpikir kritis adalah berpikir dengan baik, dan merenungkan tentang proses berpikir merupakan bagian dari berpikir dengan baik. 
Berdasarkan uraian yang dikemukakan di atas, dapat disimpulkan bahwa kemampuan berpikir kritis adalah kemampuan menggunakan logika untuk membuat, menganalisis mengevaluasi serta mengambil keputusan tentang apa yang diyakini dan dilakukan.

Suryabrata (2006: 19) mengemukakan pendapat "Suatu hasil yang dapat dicapai oleh seseorang yang belajar dalam selang waktu tertentu dapat dikatakan hasil belajar". Haryati (2007: 13) berpendapat "Penilaian hasil belajar peserta didik yang dilakukan oleh guru selain untuk memantau proses, kemajuan dan perkembangan hasil belajar peserta didik, juga sebagai umpan balik kepada guru agar dapat menyempurnakan perencanaan dan proses program pembelajaran". Kurikulum Tingkat Satuan Pendidikan (KTSP) dalam proses pembelajaran menerapkan pendekatan pembelajaran tuntas (mastery learning) dan dalam proses penilaiannya menerapkan sistem penilaian berkelanjutan yang menyangkut tiga ranah, yaitu kognitif, psikomotor, dan afektif.

Hasil belajar adalah kemampuan-kemampuan yang dimiliki siswa setelah ia menerima pengalaman belajarnya. Hasil belajar mencakup kemampuan kognitif, afektif, dan psikomotorik. Hasil belajar adalah perubahan perilaku secara keseluruhan bukan hanya salah satu aspek potensi kemanusiaan saja. Artinya, hasil pembelajaran yang dikategorisasi oleh para pakar pendidikan sebagaimana tersebut di atas tidak dilihat secara fragmentaris atau terpisah, melainkan komprehensif (Supriyono, 2009: $5-7)$.

Purwanto (2010: 45) menyatakan bahwa hasil belajar adalah perubahan yang mengakibatkan manusia berubah dalam sikap dan tingkah lakunya. Hasil belajar siswa pada hakikatnya adalah perubahan tingkah laku. Tingkah laku sebagai hasil belajar dalam pengertian yang luas mencakup bidang kognitif, afektif, dan psikomotoris. Oleh sebab itu, dalam penilaian hasil belajar rumusan kemampuan dan tingkah laku yang diinginkan dikuasai siswa (kompetensi) menjadi unsur penting sebagai dasar dan acuan penilaian. Darma (2010: 4). Penilaian proses pembelajaran adalah upaya memberi nilai 
terhadap kegiatan belajar mengajar yang dilakukan oleh siswa dan guru dalam mencapai tujuan-tujuan pengajaran.

Menurut Mulyasa (2006: 131), suatu pembelajaran dapat dinyatakan berhasil apabila seluruhnya atau setidak-tidaknya sebagian besar (75\%) siswa terlibat secara aktif, baik fisik, mental maupun sosial dalam proses pembelajaran”. Ketuntasan tersebut bukan hanya pada ketuntasan nilai kognitif, namun pada proses pembelajaran yang meliputi ranah kognitif, afektif, maupun psikomotor. Keaktifan sebagai parameter lebih mengarah pada proses pembelajaran, dimana siswa akan menjadi aktif apabila merasa sesuai dengan kondisi dan metode pembelajaran yang digunakan.

Dengan demikian hasil belajar dapat dikatakan sempurna apabila target jangkauan mengenai pencapaian tingkat sebagaimana yang telah disebutkan sesuai dengan tujuan belajar yang diharapkan siswa (Nana Sudjana, 2010: 32).

Menurut Gudeva, Dimova, Daskalovska dan Trajkova (2012: 1), hasil pembelajaran didefinisikan sebagai laporan tentang apa yang diharapkan untuk diketahui, memahami dan / atau dapat melakukan oleh para siswa pada akhir periode pembelajaran.

Berdasarkan beberapa pengertian di atas maka hasil belajar dalam penelitian ini dapat diartikan sebagai hasil dari proses belajar yang berupa angka-angka yang diperoleh dari tes baik secara tertulis maupun lisan.

Berdasarkan uraian latar belakang masalah di atas maka permasalahan dalam penelitian ini dirumuskan sebagai berikut; Bagaimanakah penerapan Peer Teaching dalam pembelajaran IPS Ekonomi dapat meningkatkan kemampuan berpikir kritis siswa kelas VII 1 SMP Negeri 1 Pasar Baru Kabupaten Simalungun Tahun 2017/2018 dan bagaimanakah penerapan Peer Teaching dalam pembelajaran IPS Ekonomi dapat meningkatkan hasil belajar siswa kelas VII 1 SMP Negeri 1 Pasar Baru Kabupaten Simalungun Tahun 2017/2018. Sesuai dengan rumusan masalah di atas, maka tujuan dalam penelitian ini adalah untuk mengetahui dan mendeskripsikan; Penerapan Peer Teaching pada pembelajaran IPS Ekonomi untuk meningkatkan kemampuan berpikir kritis siswa kelas kelas VII 1 SMP Negeri 1 Pasar Baru Kabupaten Simalungun Tahun 
2017/2018 dan Penerapan Peer Teaching pada pembelajaran IPS Ekonomi untuk meningkatkan hasil belajar siswa kelas kelas VII 1 SMP Negeri 1 Pasar Baru Kabupaten Simalungun Tahun 2017/2018.

\section{II.PEMBAHASAN}

Prosedur penelitian yang digunakan dalam penelitian ini adalah mengacu pada penelitian tindakan kelas, yaitu suatu pendekatan untuk meningkatkan pendidikan dengan melakukan perubahan ke arah perbaikan terhadap hasil pendidikan dan pembelajaran (Arikunto, 2008: 105). Penelitian tindakan kelas juga diartikan sebagai suatu penelitian yang dilakukan secara sistematis, reflektif terhadap berbagai tindakan yang dilakukan oleh guru atau pelaku, mulai dari perencanaan sampai dengan penilaian terhadap tindakan nyata di dalam kelas yang berupa kegiatan belajar mengajar untuk memperbaiki kondisi pembelajaran yang dilakukan (Basuki Wibawa, 2003: 9).

Pada kondisi awal proses belajar mengajar guru belum menerapkan model Peer Teaching, namun hanya menerapkan proses diskusi kelompok berdasarkan kedekatan tempat duduk siswa. Saat proses diskusi, hanya beberapa siswa yang terlibat dengan aktif, sebagian besar bersikap pasif, kerja sama dalam kelompok belum ada, hal ini terjadi karena pembentukan kelompok hanya berdasarkan kedekatan tempat duduk, sehingga bukan merupakan kelompok beragam kemampuan akademisnya. Kelompokkelompok hanya didominasi oleh siswa yang pandai, sehingga suasana diskusi menjadi kurang greget. Siswa yang memiliki kemampuan rendah kurang bias menanggapi pertanyaan dan jawaban yang diberikan anggota kelompok.

Hasil diskusi melalui presentasi masih belum maksimal, terkesan yang penting presentasi. Jika ada kelompok yang melakukan presentasi, kelompok lainya kurang memberikan tanggapan, pendapat, atau sanggahan sehingga suasana kelas menjadi kurang baik. Upaya guru membantu memberi motivasi belum sepenuhnya berhasil.

Berdasarkan hasil penelitian yang telah dilakukan dapat disajikan hasil sebagai berikut: kemampuan berpikir kritis siswa mengalami peningkatan dari $36 \%$ pada pra 
siklus, meningkat menjadi $64 \%$ pada siklus I, kemudian menjadi $80 \%$ dan pada siklus III menjadi $88 \%$.

Sedangkan untuk hasil belajar siswa mengalami peningkatan dari $44 \%$ dengan ketuntasan 11 siswa pada pra siklus, meningkat menjadi 68\% dengan ketuntasan 17 siswa pada siklus I, kemudian menjadi 76\% dengan ketuntasan 19 siswa dan pada siklus III menjadi $84 \%$ dengan ketuntasan 21 siswa.

Penerapan model Peer Teaching sesuai dengan teori belajar kontruktivisme, siswa mampu membangun pengetahuan baru dengan mengembangkan pengetahuan yang telah dimiliki. Siswa merekonstruksi atau membangun pengetahuan yang dimiliki dengan pengetahuan baru untuk menyelesaikan masalah. Teori konstruktivisme menyatakan suatu pendekatan terhadap belajar yang berkeyakinan bahwa orang secara aktif membangun atau membuat pengetahuannya sendiri dan realitas ditentukan oleh pengalaman orang itu sendiri pula (Abimanyu, 2008: 22).

Hasil penelitian ini sejalan dengan pendapat Arends dalam Trianto (2007: 68) bahwa peer teaching merupakan suatu pendekatan dalam pembelajaran di mana siswa mengerjakan permasalahan yang otentik dengan maksud untuk menyusun pengetahuan mereka sendiri, mengembangkan inkuiri dan keterampilan berpikir tingkat lebih tinggi, mengembangkan kemandirian dan kepercayaan diri siswa. Model peer teaching menekankan siswa dalam berkomunikasi dengan teman sebayanya maupun dengan lingkungan belajar siswa, sehingga membantu siswa menjadi lebih mandiri dalam menyelesaikan masalah yang berkaitan dengan fakta.

Model peer teaching menyediakan sebuah alternatif yang menarik bagi guru yang menginginkan maju melebihi pendekatan-pendekatan yang lebih berpusat pada guru untuk menantang siswa dengan aspek pembelajaran aktif dari model itu. Senada dengan pendapat Leo Agung (2012: 112) bahwa cara menerapkan nya dalam pembelajaran, secara umum penerapan model ini dimulai dengan adanya masalah yang harus dipecahkan oleh peserta didik. Masalah ini dapat berasal dari peerta didik ataupun pendidik. Model dirancang untuk mewakili realitas sesungguhnya, walaupun model itu sendiri bukanlah realitas dari dunia sebenarnya. 
Kegiatan pembelajaran dengan model Peer Teaching dapat menghasilkan siswa yang terbiasa menyelesaikan masalah yang diberikan, terbukti siswa kelas kelas VII 1 SMP Negeri 1 dapat menyelesaikan masalah yang diberikan guru karena menerapkan langkah-langkah model Peer Teaching dengan baik. Hal ini senada dengan hasil penelitian yang dilakukan Silviani (2013) yang menyimpulkan bahwa model Peer Teaching memberikan pengaruh yang signifikan untuk memecahkan masalah.

Model Peer Teaching memiliki keunggulan mampu meningkatkan motivasi dan aktivitas belajar siswa. Hal ini senada dengan pendapat Sanjaya, (2011:220) keunggulan model pembelajaran Peer Teaching yaitu: merupakan model pembelajaran yang cukup bagus untuk lebih memahami isi pelajaran, pemecahan masalah dapat menantang kemampuan peserta didik serta memberikan kepuasaan untuk menemukan pengetahuan baru bagi peserta didik, dapat meningkatkan aktivitas pembelajaran peserta didik, dapat membantu peserta didik untuk membentuk pengetahuan mereka untuk memahami masalah dalam kehidupan nyata, dapat membantu peserta didik untuk mengembangkan pengetahuan barunya dan bertanggung jawab dalam pembelajaran yang mereka lakukan, dapat mendorong untuk melakukan evaluasi sendiri baik terhadap hasil maupun proses belajarnya, dapat memperlihatkan kepada peserta didik bahwa mata pelajaran IPS Ekonomi pada dasarnya memerlukan cara berpikir dan sesuatu yang harus dimengerti oleh peserta didik, bukan hanya sekedar belajar dari guru atau buku-buku saja, dianggap lebih menyenangkan dan disukai peserta didik, dapat mengembangkan kemampuan peserta didik berpikir kritis dan mengembangkan kemampuan mereka untuk menyesuaikan dengan pengetahuan baru, dapat memberikan kesempatan kepada peserta didik untuk mengaplikasikan pengetahuan yang mereka miliki dalam dunia nyata, dan pemecahan masalah dapat mengembangkan minat peserta didik untuk secara terus-menerus belajar sekalipun belajar pada pendidikan formal telah berakhir.

Tindakan yang dilaksanakan menggambarkan kemampuan berpikir kritis siswa meningkat selama model Peer Teaching diterapkan. Hal ini didasarkan pada unsur yang diteliti, yaitu indikator yang telah ditetapkan, hasil tes untuk mengukur 
kemampuan berpikir kritis. Taksonomi Bloom memuat level berpikir meliputi ingatan, pemahaman, penerapan, analisis, sintesis, evaluasi. Analisis, sintesis, dan evaluasi sangat sesuai untuk pengembangan kemampuan berpikir kritis. Model Peer Teaching dan taksonomi bloom merupakan instrument dari berpikir kritis.

Hasil penelitian ini sejalan dengan penelitian Nina Abdul Razzak. (2012) bahwa Peer Teaching adalah strategi di mana siswa belajar isi kursus dengan menganalisis dan memecahkan masalah kehidupan nyata yang berhubungan dengan kursus, dimana dalam penelitian ditemukan peningkatan hasil belajar dalam psikologi pendidikan kelas, dengan pengembangan kompetensi yang lebih sesuai dengan apa yang dibutuhkan.

Penelitian tindakan ini membuktikan bahwa model Peer Teaching dapat meningkatkan hasil belajar siswa. Penilaian hasil belajar kognitif dilakukan di awal penelitian dan di setiap akhir tindakan. Hasil angket dan wawancara dengan siswa menunjukkan banwa siswa lebih menyukai dan merasa nyaman dengan penggunaan model pembelajaran Peer Teaching yang mengaktifkan dan mengeksplorasi kemampuan siswa. Dengan model Peer Teaching siswa lebih memahami materi ajar dan mampu mengerjakan evaluasi dengan optimal. Hal ini senada dengan pendapat Erik De Graaff (2003) yang menyimpulkan, dibandingkan dengan kurikulum dengan teknik tradisional, model tampaknya menginspirasi tingkat keterlibatan dalam kegiatan belajar lebih tinggi dan, akibatnya, tingkat pemahaman semakin kompleks. Keterlibatan siswa dalam kegiatan pembelajaran yang tinggi berdampak pada peningkatan hasil belajar.

Peningkatan kemampuan berpikir kritis siswa selama dilakukan tindakan dapat dilihat pada data empirik di berikut ini. 


\section{Tabel 17: Data Kemampuan Berpikir Selama Tindakan}

\begin{tabular}{|c|c|c|c|}
\hline Tahap & $\begin{array}{c}\text { Nilai } \\
\text { Tes \% }\end{array}$ & $\begin{array}{c}\text { Rata- } \\
\text { rata }\end{array}$ & $\begin{array}{c}\text { Nilai } \\
\text { Diskusi \% }\end{array}$ \\
\hline Pra Siklus & 36 & 70,80 & 41 \\
\hline Siklus I & 64 & 73,40 & 61,5 \\
\hline Siklus II & 80 & 77,20 & 82,5 \\
\hline Siklus III & 88 & 80,60 & 86,5 \\
\hline
\end{tabular}

Peningkatan hasil belajar siswa selama dilakukan tindakan dapat dilihat pada data empirik di berikut ini.

Tabel 18: Data Peningkatan Hasil Belajar Siswa Selama Tindakan

\begin{tabular}{|c|c|c|c|c|}
\hline Tahap & $\begin{array}{c}\text { Nilai } \\
\text { Terti- } \\
\text { nggi }\end{array}$ & $\begin{array}{c}\text { Nilai } \\
\text { Teren- } \\
\text { dah }\end{array}$ & $\begin{array}{c}\text { Rata- } \\
\text { rata }\end{array}$ & $\begin{array}{c}\text { Ketun- } \\
\text { tasan } \\
\%\end{array}$ \\
\hline Pra Siklus & 80 & 55 & 69,40 & 44 \\
\hline Siklus I & 85 & 60 & 73,20 & 68 \\
\hline Siklus II & 90 & 65 & 76,60 & 76 \\
\hline Siklus III & 95 & 70 & 80,20 & 84 \\
\hline
\end{tabular}

(Sumber: Data primer nilai hasil belajar)

\section{PENUTUP}

Berdasarkan hasil penelitian dan pembahasan maka yang didapat adalah Penerapan model Peer Teaching di kelas kelas VII 1 SMP Negeri 1 Pasar Baru Kabupaten Simalungun mampu meningkatkan aktivitas guru dalam kegiatan pembelajaran. Hasil akhir Siklus III mengalami peningkatan sesuai target yang ditentukan. Peningkatan ini terjadi karena persiapan yang dilakukan oleh guru sudah baik, guru sudah menjelasan tentang model Peer Teaching dengan baik sehingga siswa menjadi lebih paham, dan pengelolaan waktu sudah baik sehingga pembelajaran dapat berlangsung secara efektif. Penerapan model Peer Teaching di kelas kelas VII 1 SMP 
Negeri 1 Pasar Baru Kabupaten Simalungun mampu meningkatkan aktivitas siswa dalam kegiatan pembelajaran. Hasil akhir pada Siklus III siswa sudah mamahami dan terbiasa melaksanakan pembelajaran dengan model Peer Teaching, dalam kegiatan diskusi sudah dilakukan pembagian tugas dengan baik, sebagian besar siswa sudah aktif dalam diskusi dan presentasi, Pengaturan waktu sudah baik dan merata tiap kelompok, dan tanggapan antar kelompok dalam presentasi sudah baik. Penerapan model Peer Teaching di kelas VII 1 SMP Negeri 1 Pasar Baru Kabupaten Simalungun terbukti dapat meningkatkan kemampuan berpikir kritis siswa. Peningkatakan kemampuan berpikir kritis siswa terjadi pada setiap siklus yang dilaksanakan. Kemampuan berpikir kritis pada kondisi awal menunjukkan rata-rata sebesar 69,80 dengan ketuntasan klasikal mencapai 36\%. Setelah dilakukan tindakan pada siklus I kemampuan berpikir kritis meningkat dengan nilai rata-rata sebesar 73,40 dengan ketuntasan klasikal mencapai 64\%. Selanjutnya pada siklus II mengalami peningkatan dengan nilai rata-rata sebesar 77,20 dengan ketuntasan klasikal 80\% dan pada siklus III mengalami peningkatan kembali dengan nilai rata-rata sebesar 80,60 dengan ketuntasan klasikal mencapai 88\%. Dengan hasil tersebut, target yang ditentukan telah tercapai. Penerapan model Peer Teaching di kelas VII 1 SMP Negeri 1 Pasar Baru Kabupaten Simalungun terbukti dapat meningkatkan hasil belajar siswa. Peningkatan nilai hasil belajar terjadi pada setiap siklus yang dilaksanakan yaitu hasil belajar pada kondisi awal menunjukkan nilai rata-rata sebesar 69,40 dengan ketuntasan klasikal mencapai $44 \%$. Setelah dilakukan tindakan pada siklus I hasil belajar meningkat dengan nilai rata-rata sebesar 73,20 dengan ketuntasan klasikal mencapai $68 \%$. Selanjutnya pada siklus II mengalami peningkatan dengan nilai rata-rata sebesar 76,60 dengan ketuntasan klasikal $76 \%$ dan pada siklus III mengalami peningkatan kembali dengan nilai rata-rata sebesar 80,20 dengan ketuntasan klasikal mencapai 84\%. Dengan hasil tersebut, target yang ditentukan telah tercapai.

Berdasarkan hasil penelitian yang telah dilakukan dapat disampaikan bahwa guru dapat memilih alternatif pembelajaran model Peer Teaching untuk meningkatkan kemampuan berpikir kritis dan hasil belajar siswa. Penelitian tindakan kelas selalu 
relevan dengan kebutuhan guru untuk mengadakan inovasi dalam proses kegiatan pembelajaran, kebutuhan siswa tentang model pembelajaran yang diinginkan siswa, sehingga penelitian tindakan kelas dapat menyatukan persepsi guru dan siswa dalam perbaikan kegiatan pembelajaran.

Sebagai subyek penelitian hendaknya siswa menyadari tugas dan kewajibannya serta berpartisipasi aktif dalam kegiatan pembelajaran, agar hasil yang didapatkan menjadi semakin baik untuk kepentingan siswa di masa selanjutnya.

Kepala sekolah memberikan dukungan dengan menyediakan sarana dan prasarana pembelajaran yang memadai guna menunjang proses pembelajaran, dan memberi kebebasan guru untuk menerapkan model pembelajaran di dalam kelas sesuai dengan materi pembelajaran pada setiap mata pelajaran.

\section{DAFTAR PUSTAKA}

Amir, M. T. 2010. Inovasi Pendidikan melalui Peer Teaching. Jakarta: Prenada Media Grup.

Arends, R.I., 2007. Learning to Teach, Belajar Untuk Mengajar buku 2, Terjemahan oleh Helly Prajitno Soetjipto, dan Sri Mulyantini Soetjipto, 2008, Yogyakarta, Pustaka Pelajar.

Arikunto, Suharsimi, 2008. Penelitian Tindakan Kelas. Jakarta: Bumi Aksara.

Basuki Wibawa. 2004. Penelitian Tindakan Kelas. Jakarta : Depdiknas.

Dharma. 2010. Contextual Teaching and Learning Rayasa Research and Training. Bandung: UPI.

Haryati, Mimin. 2007. Sistem Penilaian Berbasis Kompetensi. Jakarta:Gaung Persada Pres.

Mulyasa. 2006. Kurikulum Berbasis Kompetensi. Bandung: PT Remaja Rosdakarya.

Nana Sudjana. 2005. Penilaian Hasil Proses Belajar Mengajar. Bandung: PT Remaja Rosdakarya.

Nurhadi. 2004. Kurikulum 2004 Pertanyaan \& Jawaban. Jakarta: Grasindo.

Purwanto. 2010. Evaluasi Hasil Belajar. Yogyakarta: Pustaka Pelajar.

Sanjaya, Wina. 2014. Strategi Pembelajaran Berorientasi Standar Proses Pendidikan. Jakarta: Kencana.

Suprijono, Agus. 2009. Cooperative Learning Teori dan Aplikasi PAIKEM. Yogyakarta: Pustaka Pelajar.

Suryabrata, Sumadi. 2006. Psikologi Pendidikan. Jakarta: PT Raja Grafindo.

Suwardi. 2007. Manajemen Pembelajaran: Mencipta Guru Kreatif dan Berkompetensi. Jawa Tengah: STAIN Salatiga Press. 